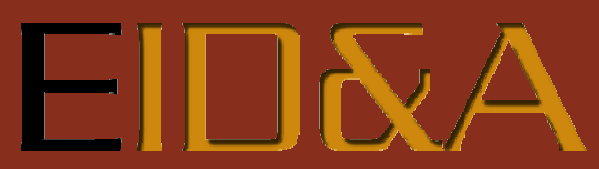

Revista Eletrônica de Estudos Integrados em Discurso e Argumentação

http://dx.doi.org/10.17648/eidea-15-1948

\title{
ARGUMENTAÇÕES E MANIPULAÇÕES NO FILME DEUS NÃO ESTÁ MORTO
}

\author{
Fernando Martins Fiori ${ }^{i}$
}

Resumo: Este artigo buscou analisar as técnicas argumentativas do filme Deus Não Está Morto (2014), realizado pela empresa Pure Flix Entertaiment, responsável por produções cinematográficas com temáticas cristãs e intuitos evangelizadores. $O$ enredo gira em torno da personagem Josh Wheaton, calouro de uma universidade, que entra em um conflito ideológico com seu professor de filosofia, Jeffery Raddison. Este nega a existência de Deus e impinge sua convicção aos alunos, mas Josh se recusa a aceitá-la e se propõe a provar o contrário, em apenas três seminários. Evidenciamos como as técnicas de argumentação mobilizadas contribuem para a construção de um fazer-persuasivo sustentado pelo objetivo de levar a crer no Cristianismo, sobretudo, por intimidação. Nosso aparato teórico consistiu, principalmente, no livro Argumentação, de José Luiz Fiorin, que nos explica as diversas possibilidades argumentativas, além da semiótica narrativa e discursiva, cuja teoria nos ajudou a detectar as manipulações presentes no filme.

Palavras-chave: Argumentação. Manipulação. Semiótica narrativa e discursiva. Cinema cristão.

Abstract: This paper aims to analyze the argumentative techniques of the film God Is Not Dead (2014), produced by Pure Flix Entertaiment, responsible for cinematographic productions with Christian themes and evangelizing intentions. The plot revolves around the character Josh Wheaton, a university freshman, who engages into an ideological conflict with his Philosophy Professor, Jeffery Raddison. Raddison denies the existence of God and impinges his conviction on the students, but Josh refuses to accept that and proposes to prove otherwise in only three seminars. We show how the argumentation techniques mobilized contribute to the construction of a persuasive-doing sustained by the goal of leading to believe in Christianity, above all through intimidation. Our theoretical apparatus consisted mainly of José Luiz Fiorin's book Argumentation, which explains the various argumentative possibilities, besides Narrative and Discursive Semiotics, theories that helped us detect the manipulations present in the film.

Keywords: Argumentation. Manipulation. Narrative and discursive semiotics. Christian cinema.

\footnotetext{
' Mestre pelo Programa de Pós-Graduação em Imagem e Som da Universidade Federal de São Carlos (UFSCar) e doutorando pelo Programa de Pós-Graduação em Linguística da Universidade Federal de São Carlos (UFSCar), Brasil. E-mail: fernandomfiori@gmail.com.
} 
EID\&A - Revista Eletrônica de Estudos Integrados em Discurso e Argumentação, llhéus, n. 15, jan./jun.2018.

\section{Introdução}

No senso comum, a propaganda serviria para induzir alguém à compra de um bem material. Porém, desde tempos remotos, tal noção está muito mais vinculada ao fazer-crer numa ideia, ou melhor, numa religião. Alex Periscinoto, um reconhecido publicitário do Brasil, em uma palestra de 1977, realizada para a $\mathrm{CNBB}^{1}$, afirma que a Igreja Católica foi a progenitora do que conhecemos hoje por propaganda. Não é por acaso que o substantivo advém do verbo italiano propagare, que significava, naquele contexto, o ato de disseminação da fé católica, cada vez mais poderosa durante a Idade Média.

Mas o cunho publicitário das religiões cristãs não ficou limitado àquela época, já que, desde então, elas acompanharam o desenvolvimento dos meios de comunicação, a partir dos quais vislumbraram possibilidades de evangelização. Dessa forma, o cinema não fica de fora dos olhares de portavozes da fé, atentos ao potencial de espectadores que o meio de comunicação abrange, investindo, por isso, cada vez mais nesse nicho de entretenimento, denominado "cinema cristão". Uma das produtoras que se propõe a fornecer um entretenimento dito "saudável" e para a "família" é a norte-americana Pure Flix Entertainment, que conta com um rol de produções de diversos gêneros audiovisuais, dentre as quais está o filme que escolhemos para este trabalho: Deus Não Está Morto², lançado em 2014 e dirigido por Harold Cronk.

O enredo gira em torno da personagem Josh Wheaton, calouro de uma universidade, que entra em conflito com seu professor de filosofia, Jeffery Raddison. Logo no primeiro dia de aula, o professor coage os alunos da sala de Josh a escreverem a famosa frase de Nietzsche, Deus está morto ${ }^{3}$, em uma folha e a assinarem embaixo. Isso serviria como uma declaração, uma maneira dos alunos se absterem de discussões filosóficas enfadonhas e obterem a aprovação direta naquela disciplina, acatando, dessa forma, a opinião do professor ateu. Porém, Josh, um cristão devoto, se nega a essa imposição e, então, sofre uma retaliação: três dias de seminários para que prove a existência de Deus, correndo o risco de receber uma média baixa e de ser reprovado no ano letivo. Apesar dos critérios de avaliação desleais do professor, Josh o convence de que, ao final do debate, a sala é que deverá decidir qual ponto de vista é plausível.

\footnotetext{
${ }^{1}$ Conferência Nacional dos Bispos do Brasil.

2 Título original em inglês: God's Not Dead

${ }^{3}$ A famosa frase do filósofo é citada, primeiramente, na obra A Gaia Ciência, publicada em 1882.
} 
EID\&A - Revista Eletrônica de Estudos Integrados em Discurso e Argumentação, Ilhéus, n. 15, jan./jun.2018.

Como elucida o semioticista Denis Bertrand (2003, p. 117), "o ponto de vista daquele que sustenta uma opinião será igualmente determinado pela maneira como ele instala o discurso de outrem, com vistas a refutá-lo ou a consolidar seu próprio discurso". Orientados por essa perspectiva, primeiramente, analisaremos os três seminários - um em cada seção -, visando identificar as técnicas argumentativas de cada debatedor à luz da teoria proposta por José Luiz Fiorin (2017), em seu livro Argumentação, no qual revisita importantes autoridades no assunto, desde os greco-latinos. Seguindo a tradição epistemológica do linguista brasileiro, concomitantemente, faremos uso da teoria semiótica narrativa e discursiva, conhecida, também, como greimasiana ou francesa. Com esse aparato teórico, propomo-nos a abordar a teia argumentativa de Deus Não Está Morto, considerando o fazer-persuasivo dos debatedores sobre o júri, assim como a manipulação ${ }^{4}$ que sustenta esse fazer, esta, por sua vez, ancorada pela veridicção, ou seja, pelo estatuto de verdade que, no intrincado jogo entre sujeitos, determina, ou não, a crença.

\section{Primeiro debate}

Chegado o dia do primeiro debate, logo de início, o professor faz uso do ataque pessoal indireto contra Josh, ou melhor, contra todos os alunos religiosos da sala (nota-se outro aluno com um crucifixo pendurado no pescoço), dirigindo-se a eles como "cabeças quadradas", "que consideram a existência de uma divindade suprema necessária, ou evidente, ou ambas" (oh, 33min, 55s). Esse tipo de argumento dirigido à pessoa é chamado de argumentum ad hominem e tem a finalidade de desqualificar "o adversário como interlocutor sério, apresentando-o como alguém incompetente, não confiável ou inconsequente." (FIORIN, 2017, p. 171).

Então, o professor chama Josh à tribuna, e este inicia sua arguição: “Os ateus dizem que ninguém pode provar a existência de Deus e estão certos. Mas digo que ninguém pode provar que Deus não existe" (oh, 34min, 50s). Até aqui, nada de surpreendente, já que o mistério da transcendência é desconhecido: mesmo com discussões em âmbito teológico, filosófico, físicomatemático, ainda existem somente especulações sobre a temática. $O$ aluno dá continuidade a sua fala, propondo que a melhor forma de debater a

\footnotetext{
${ }^{4}$ As quatro grandes classificações empregadas por Greimas e Courtés (2013), no verbete sobre manipulação no Dicionário de Semiótica, são a provocação, a sedução, a tentação e a intimidação.
} 
EID\&A - Revista Eletrônica de Estudos Integrados em Discurso e Argumentação, llhéus, n. 15, jan./jun.2018.

premissa em pauta seria colocando Deus em julgamento. Atribuir-se-ia, assim, o papel de promotor ao professor Raddison, o papel de advogado de defesa a Josh e de júri aos alunos daquela turma. Nessa fala, notamos a intencionalidade de Josh em afirmar, sorrateiramente, a existência de Deus, se esquivando da premissa do debate. E a semiótica pode nos ajudar com essa questão. Em um tribunal, o réu é aquele sujeito julgado por uma ação pretérita, por uma performance realizada, passível de uma sanção positiva ou negativa do destinador-julgador. Ora, ao atribuir a Deus um papel actancial de sujeito narrativo, o aluno está afirmando, implicitamente, sua existência, enquanto Deus, nesse debate, deveria consistir em um tema a ser discursivizado.

Após tais considerações iniciais, Josh começa sua arguição explicando a aceitabilidade da teoria do Big Bang pelos cosmólogos e descreve esse evento citando as palavras do físico ateu e ganhador do Prêmio Nobel, Steven Weinberg: "- No início, houve uma explosão, e em três minutos foram produzidos $98 \%$ da matéria que existe ou viria a existir. Tínhamos um universo" (oh, 35min, 50s). Josh continua, agora com suas próprias palavras:

- Por 2.500 anos, os cientistas concordaram com a ideia de Aristóteles de um universo imóvel. Que o universo sempre existiu, sem princípio e nem fim. Mas a Bíblia discordava. Na década de 1920, o astrônomo belga Georges Lemaître disse que o universo inteiro salta na existência em um trilionésimo de trilionésimo de um segundo, saindo do nada, num inimaginável e intenso flash de luz. É como ele esperaria que o universo reagisse se Deus fosse realmente emitir a ordem de Gênesis, 1:3 - "E que se faça a luz". Em outras palavras, a origem do universo aconteceu exatamente como se esperaria depois de ler o Gênesis, e por 2.500 anos, a Bíblia esteve certa e a ciência esteve errada. (oh, 36min).

A conclusão de Josh é baseada em uma analogia comum à figurativização das duas teses: científica e religiosa. Ele conclui que a religião esteve certa há tempos ao transpor o domínio do significado científico para o domínio do mito judaico-cristão por meio do argumentum a simili, que "tem um forte poder persuasivo, pois, nele, utiliza-se o que é conhecido para entender o que não se conhece, transpõe-se o que é válido num domínio para o outro" (FIORIN, 2017, p. 191). É o que fazem as crenças que se utilizam de postulados científicos como base para seus argumentos metafísicos. Por exemplo, citemos a terceira lei de Newton: "A toda ação há sempre uma reação oposta e de igual intensidade: as ações mútuas de dois corpos um sobre o outro são sempre iguais e dirigidas em sentidos opostos". Essa lei, consagrada como Ação e Reação, refere-se ao comportamento dos corpos 
EID\&A - Revista Eletrônica de Estudos Integrados em Discurso e Argumentação, llhéus, n. 15, jan./jun.2018.

materiais do mundo físico, mas, por outro lado, é usada fortemente a título de analogia para várias especulações no campo metafísico, como a lei de Causa e Efeito da doutrina espírita.

Vale ressaltar que o argumentum a simili utilizado por Josh persuade muito, porque traz um estatuto de verdade a sua arguição, fenômeno discursivo que a semiótica denomina de veridicção, como explica Maria de Lourdes O. G. Baldan (1988, p. 50):

Mas a veridicção que se estabelece dentro dos limites do discurso é, sempre, relativa a um sujeito modalizador, pertencente ao texto, sujeito observador intradiscursivo. É a partir do seu ponto de vista que cada enunciado virá a definirse, ali, segundo o ser e o parecer. Apreender o discurso ao modo do ser/não-ser é apreender o seu componente ideológico, ou seja, apreendê-lo como um efeito das manipulações modais que o engendram.

Contudo, ao associar o mito religioso ao discurso científico - o qual desperta confiabilidade -, Josh, como sujeito observador, interpreta ideologicamente a modalidade veridictória do parecer verdadeiro, relativo ao Criacionismo, no nível da manifestação, como a do ser verdadeiro, no nível da imanência.

Ainda discursando sobre o início do universo, Josh defende a indicação de um Deus que o criara: "- No mundo real, nunca vemos nada saltar para a existência partindo do nada, mas os ateus querem fazer uma pequena exceção a essa regra. Tipo, o universo e tudo o que ele contém" (oh, 38min, 25s). Então, uma aluna interpela Josh que, em seguida, retruca:

[Aluna] - Mas, no livro Deus, um delírio, Richard Dawkins disse que se me disser que Deus criou o universo, então eu tenho o direito de me perguntar quem criou Deus.

[Josh] - A pergunta de Dawkins só tem sentido em termos de um Deus que tenha sido criado e não tem sentido de um Deus que não foi criado que é o tipo de Deus que os cristãos acreditam. (oh, 38min, 40s).

Na pergunta da garota, há o argumento de causalidade, fundamentado na estrutura da realidade: se algo existe, alguém o originou, como um ser humano, que advém da relação sexual de um homem e uma mulher. Essas são as regras do mundo objetivo. No entanto, para a religião, as significações mundanas transcendem o senso comum, e, com isso, as regras de implicação são substituídas pelas de concessão. Como explica Claude Zilberberg (2006, p. 196-197), "a implicação fala das regularidades, a concessão rompe com as expectativas e dá acesso à descontinuidade do que é marcante na vida". Josh, 
EID\&A - Revista Eletrônica de Estudos Integrados em Discurso e Argumentação, llhéus, n. 15, jan./jun.2018.

continuando sua explanação, reverte a pergunta da colega, utilizando-se do próprio argumento de causalidade desta para repensar o choque entre implicação e concessão: "- Se o universo criou você, então quem criou o universo? Tanto o teísta quanto o ateísta carregam o fardo de responder a mesma pergunta de como tudo começou." (oh, 39min 05s). Ele finaliza o primeiro debate dirigindo-se ao auditório, deixando-o muito reflexivo:

- O que eu espero que vocês entendam de tudo isso é que não precisam cometer suicídio intelectual para crer num criador por trás da criação. Na medida em que você acredita em Deus, seria bastante pressionado a achar uma incrível explicação ou alternativa sobre como as coisas surgiram (oh, 39min 20s).

Essa estratégia vai ao encontro do recurso de convencimento chamado argumentum ad populum, no qual "apela-se para os sentimentos coletivos de uma plateia, explorando tanto as emoções positivas quanto os preconceitos, para ganhar a adesão a uma tese que não se sustenta em razões pertinentes ao tema em discussão." (FIORIN, 2017, p. 224). Como emoção positiva, segundo Josh, seríamos recompensados com a explicação existencial que nos perturba, seres pensantes: a curiosidade sobre de onde viemos e para onde vamos. Quanto ao preconceito, ele refere-se à resistência acadêmica dos professores ateus às religiões.

No final do debate, o professor Raddison ressalta o fato de o aluno ter evitado a consulta aos estudos de Stephen Hawking, uma das maiores autoridades científicas do mundo, que defende um universo autocriado por geração espontânea: "o argumento de autoridade mais poderoso é a instalação de um ator, a manifestação de um actante da modalidade do saber, que é tomado como garantia da verdade de um enunciado" (FIORIN, 2017, p. 262). Josh, titubeando, fica sem resposta, e seu professor, intrépido, o desqualifica diante da sala: "- Eu praticamente estouro o balão de seu argumento inteiro com um alfinete e você não sabe?" (oh, 40min, 55s). Josh responde que gostaria de ter uma resposta perfeita, mas, independentemente disso, sua fé é inabalável; o professor o ironiza; o debate termina e a sala é dispensada. Com o argumento de autoridade de Hawking, Raddison desestabilizou o seu opositor, sugerindo um breve recorte de outro ponto de vista teórico para a explicação do universo que será, no próximo debate, contestado por Josh. 
EID\&A - Revista Eletrônica de Estudos Integrados em Discurso e Argumentação, Ilhéus, n. 15, jan./jun.2018.

\section{Segundo debate}

Enquanto no primeiro debate o aluno saiu desacreditado, vencido pela provocação ${ }^{5}$ do professor, no segundo, ele sairá vitorioso, revisitando as considerações teóricas de Stephen Hawking, das quais o professor havia lançado mão. Josh recorre ao livro O Grande Projeto para iniciar o seu debate, fazendo a seguinte citação: “- Por existir a lei da gravidade, o universo pode e vai criar a si mesmo do nada" (1h, 03min, 20s). Em seguida, refuta a tese da geração espontânea do universo, baseando-se nas considerações do professor John Lennox, que prevê três erros de lógica no enunciado de Hawking, desvalidando tal hipótese por tratar-se de um raciocínio circular. 0 garoto explica:

- Hawking, basicamente, diz que o universo existe porque o universo precisa existir. E porque o universo precisa existir, ele, portanto, criou a si mesmo. É assim. Se eu digo a vocês que posso provar que o presunto é a melhor comida do mundo. A melhor que já existiu, porque em toda a história nunca existiu comida com sabor melhor. Vocês iam me olhar esquisito e dizer que eu não sei de nada, e vocês estão certos. O que eu fiz foi reafirmar a minha ideia original. Mas quando Hawking afirma que o universo criou a si mesmo, porque precisava criar a si mesmo e oferece isso como explicação de como e porque foi criado, não reconhecemos que ele está fazendo a mesma coisa. Mas está. (1h 03 min, 50s).

Parece plausível esse problema lógico levantado por Josh, salientando tautologias, que "são juízos cujo predicado não acrescenta nenhuma informação ao sujeito" (FIORIN, 2017, p. 117). No entanto, é necessário deixar claro que, para o completo entendimento de fragmentos isolados de um texto, precisaríamos ter conhecimento do contexto que o inclui. Ou seja, o recorte desse único enunciado usado por Josh poderia ser tendencioso, já que não temos conhecimento de todo o conteúdo do livro de Stephen Hawking e que este pode apresentar explanações mais profundas sobre o assunto em questão.

Para endossar o "erro" de Hawking, Josh recorre a outra citação de Lennox, que, de forma irônica, desmoraliza o pensamento do físico inglês: “Besteira permanece besteira, mesmo quando falada por cientistas famosos" (1h, 4min, 45s). Percebe-se, novamente, o já mencionado argumentum ad

\footnotetext{
5 "Na provocação e na sedução, o destinador diz ao destinatário, de forma clara ou implícita, o que sabe de sua competência, colocando-o em posição de escolha forçada. Na provocação, deve escolher entre aceitar a imagem desfavorável que dele foi apresentada ou fazer o que o manipulador pretende; na sedução, precisa recusar a representação lisonjeira que dele foi feita ou deixar-se manipular" (BARROS, 2001, p.37).
} 
EID\&A - Revista Eletrônica de Estudos Integrados em Discurso e Argumentação, Ilhéus, n. 15, jan./jun.2018.

hominem: "Essa forma de resposta dirige-se à audiência e não ao oponente. Ela busca silenciá-lo, ao pôr em dúvida sua confiabilidade. Nesse argumento, confrontam-se a pessoa com seus discursos ou atos" (FIORIN, 2017, p. 171).

O professor interfere, chamando o aluno de arrogante, pois ele é um simples calouro contradizendo uma asserção do maior cientista do mundo. Josh defende-se, respondendo que apenas concorda com as confrontações teóricas de outro acadêmico e até chega a embaraçar Raddison, quando comenta outra citação de Stephen Hawking na qual diz que a filosofia está morta: "- E se tem tanta certeza da infalibilidade do professor Hawking, e a filosofia estiver mesmo morta, então não há necessidade dessa aula" (1h, $5 \mathrm{~min}, 5 \mathrm{~s})$. Os alunos riem daquilo, e o professor irrita-se com a situação paradoxal inferida por Josh.

Deixando de abordar questões do campo da Física, Josh volta agora o seu pensamento para o darwinismo, posicionamento que considera as formas de vida complexas, como a humana, resultantes da evolução das espécies a partir de um único organismo simples:

- Nos últimos 150 anos, os darwinistas vêm dizendo que Deus é desnecessário para explicar a existência humana, e que a evolução substitui Deus. Mas a evolução só nos diz o que acontece depois que se tem vida. Então, de onde vem esta coisa que está viva? Bom, Darwin nunca resolveu isso. Presumia que, talvez, um raio caiu num lago estagnado, cheio do tipo certo de substância, e, bingo! Uma coisa viva. Mas não é tão simples assim. Vejam, Darwin afirmava que o ancestral de todas as coisas vinha daquele único organismo simples, que se reproduziu e foi lentamente se modificando com o tempo até se tornarem as formas de vida complexas que vemos hoje. E é por isso que, depois de contemplar a sua própria teoria, Darwin formou sua famosa declaração: 'A natureza não dá saltos' (1h, 07 min).

Pode-se dizer que o aluno foi presunçoso ao dizer isso, pois a religião só resolveu o problema da existência para aqueles que creem nela. Não há provas científicas da existência de Adão e Eva, só especulações a partir de textos do Gênesis, de autoria desconhecida, no Antigo Testamento. Ou seja, da mesma forma que se especula que a vida humana proveio do barro, matéria usada por Deus para criar o ser humano, poder-se-ia especular que a existência surgiu de um simples raio. Josh continua sua arguição citando outro teórico:

— Como o notável autor Lee Strobel indicou, se pudermos ilustrar os 3,8 bilhões de anos, em que os cientistas dizem existir vida, num dia de 24 horas, e no espaço de uns 90 segundos, a maioria dos principais grupos de animais surgiram, de repente, nas formas que têm atualmente. Não devagar e constantemente 
EID\&A - Revista Eletrônica de Estudos Integrados em Discurso e Argumentação, Ilhéus, n. 15, jan./jun.2018.

como Darwin previu, mas, em termos evolucionários, quase instantaneamente. Então, a natureza não dá saltos, se torna. A natureza dá um salto gigante! Como os teístas explicam essa explosão súbita de novas informações biológicas? (1h, $07 \mathrm{~min}, 55 \mathrm{~s})$.

Josh utiliza dados numéricos a fim de aparentar objetividade em suas considerações e, novamente, recorre ao argumentum a simili, colocando em relevo as considerações de Lee Strobel com a passagem bíblica presente no livro de Gênesis, em que Deus determina a origem de tudo: "Encham-se as águas de seres vivos e voem as aves sobre a terra sobre o firmamento do céu. Assim, Deus criou os grandes animais aquáticos e os demais seres que povoam as águas de acordo com suas espécies. E Deus viu que ficou bom" (Gn, 1:20). $O$ aluno termina sua arguição como se fosse uma verdade incontestável, ressaltando que houve a criação pelo fato de Deus dizer que deveria ser assim.

Quando todos os alunos deixam a sala, Raddison dirige-se a Josh e o acusa de usar da mentira para convencer o "júri”. É evidente que o professor tem sua opinião irrevogável sobre Deus e sente-se ameaçado pela desenvoltura de Josh. Mostrando o seu conhecimento bíblico, Raddison cita uma passagem do livro de Jó ${ }^{6}$, como que para negar a benevolência divina. Indignado com o amargor do professor, Josh pergunta-lhe o que havia acontecido de tão grave para odiar Deus daquela forma, e, então, o acadêmico revela que havia perdido sua mãe, quando tinha apenas 12 anos. Ela, uma devota, fora vítima do câncer; e, por mais que Raddison implorasse pela vida de sua mãe, suas preces não foram atendidas. Por fim, ele diz: “Um Deus que permite isso não merece nenhuma crença” (1h 11min 50s). O professor sai da sala, deixando Josh pensativo com aquela confissão.

\section{Terceiro debate}

Depois do segundo debate caloroso, que deixou Josh mais confiante, o professor, antes da apresentação, tenta amedrontar seu aluno, dizendo que o havia subestimado, mas que, neste último debate, iria dedicar-se a desmoralizá-lo. Isso é notado, pois, agora, ambos ficam frente a frente, como num debate político, e não mais como num seminário. Josh começa sua

\footnotetext{
${ }^{6}$ Esse livro, presente no Antigo Testamento, conta a história de resignação de Jó, que sofre severas privações como forma de Deus testá-lo através da fé e da obediência. No filme, o professor cita o personagem bíblico para demonstrar a prepotência, a severidade e a indiferença de Deus com os seus seguidores.
} 
EID\&A - Revista Eletrônica de Estudos Integrados em Discurso e Argumentação, llhéus, n. 15, jan./jun.2018.

arguição comentando sobre os males da vida, que são as armas argumentativas do ateísmo contra a fé:

- Se Deus é todo o bem, e Deus é todo poderoso, por que permite que o mal exista? [...] Deus permite que o mal exista por causa do livre arbítrio. Do ponto de vista cristão, Deus tolera o mal neste mundo temporariamente para que, um dia, quem optar por amá-lo livremente vá morar com ele no céu, sem a influência do mal, mas com o seu livre arbítrio intacto. Em outras palavras, a intenção de Deus em relação ao mal é, um dia, destruí-lo (1h, 21min).

Essa é uma hipótese pertinente a uma visão estritamente religiosa e, agora, já não se nota mais uma discussão com pressupostos teóricos contundentes, mas um conflito ideológico e uma tentativa explícita e ostensiva de convencimento do júri, principalmente por parte de Josh, que, no decorrer dos debates, manipula a plateia por tentação ${ }^{7}$, mostrando o conforto existencial que a crença no Cristianismo oferece a sujeitos passionais modalizados por um valor cognitivo: a curiosidade, o querer-saber de onde viemos e para onde vamos.

O professor ironiza as últimas explicações do garoto, confrontando a hipótese do livre-arbítrio: “- Mas que conveniente! Um dia, eu vou me livrar de todo o mal do mundo, mas até lá vocês vão ter que sofrer com todas as guerras, holocaustos, tsunamis, pobreza, fome e aids. Tenham uma boa vida!" (1h 21min, 40s). Rindo sarcasticamente, Raddison diz que, depois do que seu adversário explicou, só lhe faltava começar a palestrar sobre valores morais absolutos também. Josh retruca:

— Mas, por que não? O professor Raddison é claramente um ateu, não acredita em absolutos morais. Mas na sua ementa diz que ele pretende aplicar um exame nas últimas semanas. Agora, aposto que se eu conseguir uma nota A por colar no exame, de repente, ele vai falar como cristão, insistindo que é errado colar e que eu devia saber. Contudo, que base ele tem? E se meus atos são calculados para me ajudar a vencer, então por que eu não devo realizá-los? Para os cristãos, o ponto fixo da moralidade, o que constitui certo e errado, é uma linha reta que leva direto para Deus (1h, 21min, 55s).

Então, Raddison questiona Josh sobre a necessidade de um Deus para sermos morais, o que nos leva a pensar se seria impossível a moralidade sem uma relação com uma divindade. Sem considerar qualquer outra forma de

\footnotetext{
7 “Na tentação e na intimidação, o manipulador mostra poder e propõe ao manipulado, para que ele faça o esperado, objetos de valor cultural, respectivamente positivo (dinheiro, presentes, vantagens) e negativo (ameaças)" (BARROS, 2001, p. 37).
} 
EID\&A - Revista Eletrônica de Estudos Integrados em Discurso e Argumentação, Ilhéus, n. 15, jan./jun.2018.

pensamento, qualquer outro ponto de vista, Josh recorre a valores estritamente cristãos, sendo categórico em seu argumento:

- Não. Sem um Deus não existe motivo real para ser moral. Sabe, nem existe um padrão do que é um comportamento moral. Para cristãos, mentir, colar, roubar, no meu exemplo, colar uma nota que não me pertence é proibido. É uma forma de roubo. Mas, se Deus não existe, como Dostoievski afirmou famosamente: "Se Deus não existe, então tudo é permitido". E não só permitido, mas sem sentido. Se o professor Raddison está certo, então tudo isso, toda a nossa luta ou o nosso debate, o que decidimos, aqui, não tem sentido. Nossa vida e, por último, nossa morte não tem mais importância do que o peixinho dourado. (1h, 22min, 40s).

Com tamanha rigidez, nota-se na explanação de Josh o argumento do terceiro excluído, que "apresenta duas posições como as únicas possibilidades existentes, não admitindo nenhuma posição intermediária entre os dois polos considerados incompatíveis e considerando impossível não aceitar uma das duas posições" (FIORIN, 2017, p. 145). Ou seja, para ele, são desconsiderados outros códigos morais atrelados a diversas teologias espalhadas pelo mundo. Ou, mesmo, que a moral possa estar direcionada para a coletividade independentemente de uma entidade superior, uma vez que uma conduta moral repercute no bem-estar social.

Daqui em diante, a discussão se desloca para o campo pessoal, e os argumentos não se referem mais às proposições inicias do debate. Josh expõe o professor como antimodelo para a sala, denunciando suas coerções, sua conduta opressora, num procedimento chamado de ignoratio elenchi, que "visa a desqualificar o adversário, seja mostrando-o implicado numa situação condenável, seja apresentando-o como alguém que não é capaz de ver a questão de fundo de um debate" (FIORIN, 2017, p. 216).

A discussão continua acalorada em meio a ofensas e assunções de verdades, segundo as opiniões contrárias de cada uma das partes. Raddison interfere, ridicularizando Josh e dizendo que este resume toda a palestra na escolha entre crer ou não no seu Deus. Josh responde:

[Josh] — Isso aí. Só existe isso. É só o que sempre existiu. A única diferença entre a sua posição e a minha posição é que você sequestra a escolha deles. Você exige que escolham a frase que diz: eu não acredito.

[Raddison] - É porque eu quero libertar todos eles. Porque a religião é como um vírus letal que os pais vêm passando para os próprios filhos. E o Cristianismo é o pior de todos os vírus, entra lentamente nas nossas vidas quando estamos fracos, doentes ou indefesos.

[Josh] — Então a religião é uma doença?

[Raddison] — Exatamente! Ela infecta tudo. Ela é inimiga da razão. 
EID\&A - Revista Eletrônica de Estudos Integrados em Discurso e Argumentação, Ilhéus, n. 15, jan./jun.2018.

[Josh] — Razão? Professor, você abandonou a razão há muito tempo. O que ensina aqui não é filosofia, não é nem mais ateísmo. Mas o que ensina aqui é anti-teísmo. Já não basta que você não creia, precisa que todo mundo não creia com você.

[Raddison] — Por que não admite a verdade? Por que só quer capturá-los com a sua superstição primitiva?

[Josh] — O que eu quero mesmo é que façam a sua própria escolha. É isso o que Deus quer.

[Raddison] — Você não faz ideia de quanto me agrada reprovar você.

[Josh] — Mas quem você quer mesmo reprovar, professor? Eu ou Deus? (1h, 23min, 30s).

A sala permanece silenciosa. Nesse momento, há uma verossimilhança da disposição espacial dos atores como se estivessem, de fato, num julgamento, em que o aluno alude a um promotor inquirindo um réu, representado pelo professor. Josh apela para questões pessoais do acadêmico, perguntando o motivo de ele odiar tanto Deus e constrangendo-o com tal pergunta capciosa. Raddison, relutando em responder, vai se enfurecendo, enquanto Josh o pressiona, inquirindo-o de forma ostensiva. De repente, o professor exclama: "- Porque ele acabou tirando tudo de mim! Sim, eu odeio Deus! Tudo que sinto por ele é ódio!” (1h, 25min, 10s).

Todos ficam em silêncio. Josh encerra o debate interpelando Raddison sobre como poderia odiar alguém que não existe. A resposta mal articulada do professor causou sua derrocada e foi bem usufruída por Josh, que alterou o ponto de vista de seu adversário: o que o professor quis dizer, de fato, foi que, desde a sua infância até a morte dolorosa de sua mãe, ele acreditava em Deus; depois disso, não mais. Atrapalhado, Raddison diz que esse debate não provou nada e Josh relembra que é o júri, ou melhor, os alunos da sala, que darão o veredicto. Aos poucos, estes vão se revelando e, finalmente, decidem a favor da existência de Deus. Tal conclusão vai ao encontro da petição de princípio:

Na verdade, é uma manobra daqueles que não têm como comprovar suas afirmações e precisam fazer parecer que elas são verdadeiras. Não se trata de uma falha de argumentação, mas de uma astúcia para convencer os outros de que é verdade o que é falso ou de que é falso o que é verdadeiro (FIORIN, 2017, p. 214).

O que realmente estava em pauta, a premissa básica, que consistia na existência ou não de Deus, foi concluída como fato positivo pelo clamor da maioria dos alunos antes mesmo de alguma comprovação (se é que seria possível comprovar tal premissa, pois ela parece ser muito mais da ordem de 
EID\&A - Revista Eletrônica de Estudos Integrados em Discurso e Argumentação, llhéus, n. 15, jan./jun.2018.

uma probabilidade do que da exatidão científica). Principalmente por isso, nesse debate, foi eficaz a forma como Josh articulou os argumentos de autoridades e apelou para o emocional do público, o que resultou no acolhimento de sua ideia perante o júri, que aceitou o contrato fiduciário proposto pelo aluno: a crença em Deus.

\section{Outras estratégias argumentativas}

Além do eixo narrativo principal entre Josh e Raddison, há ainda, em Deus Não Está Morto, outras histórias paralelas com personagens interconectadas, como Martin, um estudante chinês que assiste aos debates e, à revelia de seu pai, se questiona sobre a existência de Deus. Há também o reverendo Dave, que auxilia algumas personagens em suas provações, como Aysha, uma estudante imigrante de família muçulmana, cujo pai, muito tradicionalista, Ihe obriga a usar turbante na escola, embora ela esteja em um país liberal como os EUA. Em segredo, Aysha contempla a fé cristã, mas, quando é descoberta, seu pai a expulsa de casa e, desamparada, ela acaba contando com o acolhimento do reverendo Dave. Este ampara outras personagens, como o próprio Josh, que se vê desconfortável quanto a sua situação: debater com o professor, correndo o risco de retaliações, ou ceder à imposição do acadêmico, negando sua fé. Além de Aysha e Josh, o reverendo também oferece apoio a Mina, namorada de Raddison, que se sente subjugada pela arrogância do professor, principalmente, pelo fato de ser cristã.

Em meio às tensões entre crer ou não crer, que fundamentam todo o conteúdo do filme, nota-se, pela constituição das personagens, a apresentação de modelos de virtudes, como os crentes, os quais são resignados, cordiais e determinados para provarem sua fé. Por outro lado, os descrentes são representados por paixões infames, consideradas pecados capitais, como a soberba de Raddison e Amy, a avareza de Mark, a ira do pai de Aysha, antimodelos a serem evitados. Nesse ínterim, destacaremos dois percursos narrativos que merecem atenção: os das personagens Raddison e Amy.

Paralelamente ao debate de Josh, o filme mostra a vida privada de Raddison com Mina, que acaba rompendo o namoro, pois aquele não the atribuía o devido valor. Ao final de seu percurso, Raddison sente falta da exnamorada e vai a sua procura, no show da banda Newsboys; distraído, ao 
EID\&A - Revista Eletrônica de Estudos Integrados em Discurso e Argumentação, llhéus, n. 15, jan./jun.2018.

atravessar a rua quando o sinal ainda está vermelho, é atropelado por um carro. No local, os reverendos Dave e Jude presenciam o acidente e correm para amparar a vítima agonizante. Dave pergunta se Raddison conhece Jesus, mas este responde ser um ateu. Entretanto, o reverendo acredita que a misericórdia divina o trouxe até ali, naquele exato momento, para interceder por Raddison, que não vê nada de misericordioso naquilo, já que está morrendo. Dave o contesta, porque acredita que aqueles últimos suspiros são uma dádiva, uma chance de redenção para Raddison, que poderia ter morrido na hora. Então, Dave the propõe a absolvição: "- Deus está disposto a perdoar os seus pecados. Todos eles. Se aceitar o filho dele e convidá-lo para a sua vida. É só isso que tem que fazer, é só aceitar o filho dele. Aceitar o amor dele e receberá o perdão agora" ( $1 \mathrm{~h}, 42 \mathrm{~min}$ ). O professor, muito temeroso diante de seu fim, concorda em aceitar Jesus como o seu salvador e morre.

Apesar da ocasião triste, o reverendo Jude sorri e diz que aquele acontecimento é motivo para comemoração, pois haveria alegria no céu, já que uma alma pôde ser salva em seus últimos instantes. Isso implica o seguinte questionamento: se Raddison não tivesse aceitado Jesus, sua alma não teria entrada no céu? Com essa cena, o filme evidencia a posição restritiva da religião contra os infiéis, reverberando os dizeres de Cristo, segundo o evangelho de Mateus: "Portanto, quem der testemunho de mim diante dos homens, também eu darei testemunho dele diante de meu Pai que está nos céus. Aquele, porém, que me negar diante dos homens, também eu o negarei diante de meu Pai que está nos céus" ( $M t, 10: 32-33$ ).

Voltemo-nos agora para a personagem Amy, uma jornalista estritamente engajada com o seu trabalho, o blog A Nova Esquerda. Sua primeira ação na história acontece quando ela entrevista Willie Robertson, integrante do reality show Rei dos Patos, conhecido por mostrar a vida campestre de caça dos sulistas estadunidenses. Willie está prestes a entrar na igreja com sua esposa, quando Amy o intercepta com perguntas capciosas sobre os negócios lucrativos de maquinários de caça da sua família. Ele é receptivo, aceita fazer a entrevista e responde cordialmente, dizendo que leva uma vida boa com os lucros de seu investimento. Em seguida, Amy o provoca, perguntando o que o levava a pensar ter direito de causar a morte dos animais, se ele se orgulhava de expor isso em seu programa, no qual mostrava abertamente sua fé em Jesus. Ele diz se orgulhar sim e afirma que ninguém é obrigado a assistir ao seu 
EID\&A - Revista Eletrônica de Estudos Integrados em Discurso e Argumentação, llhéus, n. 15, jan./jun.2018.

programa. Continuando a responder para Amy, ele faz uma pregação sobre a sua fé em Cristo, o único capaz de julgá-lo.

Para a blogueira, é paradoxal associar os atos de caça de Willie considerados por ela como malévolos - e a sua devoção, que deveria defender a preservação da vida de todos os seres. Mas, para Willie, assim como para os seguidores da Bíblia, a soberania dos homens perante os outros animais é permitida, pois está prescrito no livro de Gênesis, quando Deus cria todos os seres e outorga ao homem dominar "sobre os peixes do mar, sobre as aves dos céus e sobre todos os animais que se arrastam sobre a terra" (Gn, 1: 28). Além do discurso religioso, percebe-se a ressonância de outros discursos, como o político, entre direita e esquerda, notório a partir do nome do blog de Amy - A Nova Esquerda - e da postura sulista de Willie, que vai ao encontro de ideias mais conservadoras.

Com essa aparição de Willie, de Rei dos Patos, se constata o apelo à popularidade de celebridades da mídia norte-americana, que exercem influência sobre o espectador. Deus Não Está Morto termina com um grande show da banda cristã Newsboys, em espaço lotado onde estão reunidas, também, todas as personagens crentes, que celebram a palavra de Deus entoando música pop. Ao final de uma canção, o vocalista pede para que o público assista ao vídeo de Willie Robertson, que é projetado em um telão suspenso no palco. No vídeo, o sulista menciona a discussão em torno do debate de Josh e seu professor, ironizando o último e dizendo que os relatos sobre a morte de Deus foram exagerados. Ele pede para que todos, tanto os presentes no show quanto os espectadores do filme, peguem seus celulares e disseminem a mensagem "Deus não está morto" para o máximo de pessoas, numa tentativa de propaganda viral pelo dispositivo de comunicação.

Voltando-nos, novamente, para Amy, tudo muda em sua vida ao descobrir que está com câncer. Diante da doença, seu namorado, Mark, sujeito deveras egocêntrico, com receio do problema que poderia lhe sobrar, decide romper o namoro. Amy, ateia até aquele momento, está desolada e desesperada, mas encontra amparo e esperança no Cristianismo quando entrevista os Newsboys, momentos antes de entrarem no palco do show final. A princípio, ela começa a entrevista com perguntas ácidas, como fizera para Willie Robertson, mas logo é desarmada pela pregação e benevolência dos músicos. Ao orarem por Amy, eles pedem a Deus que a cure, a transforme, dando-lhe uma nova oportunidade (pedido que será concedido na 
EID\&A - Revista Eletrônica de Estudos Integrados em Discurso e Argumentação, Ilhéus, n. 15, jan./jun.2018.

continuação da série, em Deus Não Está Morto $2^{8}$, em que Amy direcionará todo o seu engajamento jornalístico para as causas cristãs).

Assim como no percurso narrativo de Raddison, também observamos no de Amy certas regularidades de acontecimentos: a descrença, a advertência (o atropelamento do professor e o câncer de Amy) e, em seguida, a resignação frente ao medo da morte e da condenação reservada ao descrente. A partir desses percursos evidenciados, em nosso plano de leitura de Deus Não Está Morto, inferimos o uso implícito da intimidação, indo ao encontro do argumentum ad baculum, que "concerne a uma manipulação segundo a modalidade do poder. É uma intimidação, ou seja, uma ameaça de levar o enunciatário a entrar em conjunção com um objeto de valor negativo" (FIORIN, 2017, p. 262). É o que ocorre com Raddison e Amy, que, ao final, sentem-se ameaçados por serem descrentes, o que os levaria à conjunção com a condenação infernal da alma, enquanto a crença no Cristianismo promete a salvação paradisíaca:

Quando se pensa a enunciação como um ato e, portanto, analisável como uma narrativa (fazer ser), a argumentação diz respeito, de um lado à manipulação (fase da narrativa em que um sujeito leva outro a dever ou querer fazer/ser); de outro, à sanção (fase da narrativa em que se estabelece a verdade ou não de um enunciado) (FIORIN, 2017, p. 259-260).

Portanto, o filme analisado, compreendido como um ato de enunciação, claramente busca persuadir o espectador a seguir os valores cristãos. Além da intencionalidade de fazer-crer, pressuposta em toda manipulação, há em Deus Não Está Morto, sobretudo, a atribuição modal do dever aceitar o Cristianismo e, consequentemente, ser cristão, como única alternativa de redenção. Isso se dá, também - segundo o plano de nossa leitura - por meio do engano estatuto veridictório do que parece ser verdadeiro, mas não é - disseminado pelo todo de sentido do filme, que tem sua premissa inicial - provar a existência de Deus - abandonada, em favor de argumentos que, afinal, voltaram-se para a desqualificação do descrente.

\footnotetext{
${ }^{8}$ A segunda série da franquia de Deus Não Está Morto (2016) conta a história da professora de ensino médio Grace Wesley. Ao ser interpelada por sua aluna Brooke sobre Jesus Cristo e responder a pergunta, Grace sofre retaliações no seu emprego. Negando-se a retratar-se, já que acredita que não fez nada de errado, a professora é processada judicialmente pelos pais ateus da aluna e, agora, ela precisará provar sua inocência sem perder a fé em Cristo. Para isso, contará com a ajuda de Amy recém-convertida, que se servirá de seus dons jornalísticos para influenciar no julgamento.
} 
EID\&A - Revista Eletrônica de Estudos Integrados em Discurso e Argumentação, Ilhéus, n. 15, jan./jun.2018.

\section{Considerações finais}

Este trabalho analisou, prioritariamente, o debate entre o aluno Josh e seu professor de filosofia, evidenciando e classificando as técnicas argumentativas das quais, principalmente, Josh se valeu para convencer seus colegas de sala a crerem no seu ponto de vista. Dos vários tipos de estratégias usados, preponderaram os argumentos de autoridades acadêmicas, tanto de cientistas ateus - como Stephen Hawking - quanto de cientistas religiosos como John Lennox -, que tiveram suas teses postas em relevo, o que deu credibilidade à arguição de Josh. Além das autoridades científicas, o filme apelou para a popularidade de celebridades - como Willie Robertson, do reality show Rei dos Patos, e a banda de pop cristão Newsboys -, que exercem grande influência sobre o público espectador. Houve ataques pessoais entre ambos os debatedores, mas o que definiu a vitória de Josh foi, sobretudo, o seu apelo às emoções tanto do professor quanto do júri. No final, a premissa básica - a existência de Deus - não foi comprovada, mas aceita como verdade pela maioria dos julgadores diante da astúcia argumentativa de Josh.

Como fase inerente às argumentações evidenciadas, identificamos as manipulações mobilizadas pelas personagens, no âmbito da estratégia persuasiva da produtora cinematográfica Pure Flix em relação ao público espectador. No debate, Josh se valeu, inicialmente, da tentação, ao propor para os seus colegas o conforto de um saber religioso que supre qualquer desejo por respostas existenciais. Prestes a morrer, Raddison é também visitado pela tentação provocada pelo reverendo Dave, que lhe promete, com a aceitação de Cristo, o perdão de seus pecados e a entrada direta para o céu. Em oposição, notamos a presença contundente da intimidação: ainda que não explorada explicitamente, a ameaça de condenação pairou sobre os descrentes e se mostrou decisiva em momentos críticos, em especial com a aproximação da morte.

Do passado cruel medieval, quando o Cristianismo era imposto à força, hoje, vemo-lo ser propagado por outros artifícios, pelos meios de comunicação de massa e pela cultura pop, que gozam de forte potencial persuasivo e alcance de público. Os porta-vozes cristãos, utilizando-se das mais variadas técnicas argumentativas, sempre pretenderão levar-nos à conversão, a crer em sua doutrina como uma verdade absoluta, e caberá a nós, consumidores de tais textos midiáticos, aceitarmos ou não tal contrato proposto. 
EID\&A - Revista Eletrônica de Estudos Integrados em Discurso e Argumentação, Ilhéus, n. 15, jan./jun.2018.

\section{Referências}

BALDAN, Maria de Lourdes Ortiz Gandin. Veridicção: um problema de verdade. Alfa: Revista de Linguística, São Paulo, v. 32, p. 47-52, 1988.

BARROS, Diana Luz Pessoa de. Teoria do discurso: fundamentos semióticos. 3.ed. São Paulo: Humanitas, 2001.

BERTRAND, Denis. Caminhos da Semiótica literária. Bauru: EDUSC, 2003.

BÍBLIA. Português. Bíblia Sagrada. Trad. Monges de Maredsous. 151.ed. São Paulo: Ave-Maria, 2002.

DEUS não está morto. Direção: Harold Cronk. Pure Flix Productions. EUA: 2014. Disponível em: <https://megafilmesonlinehd.org/assistir-deus-nao-esta-mortodublado-online.html> Acesso em: 02 out. 2017.

DEUS não está morto 2. Direção: Harold Cronk. Pure Flix Productions. EUA: 2016. Disponível em: < http://megafilmes.org/deus-nao-esta-morto-2/> Acesso em: 15 nov. 2017.

FIORIN, José Luiz. Elementos de análise do discurso. 2.ed. São Paulo: Contexto, 1990. . Argumentação. 1. ed. São Paulo: Contexto, 2017.

GREIMAS, Algirdas; COURTÉS, Joseph. Dicionário de Semiótica. 2.ed. São Paulo: Contexto, 2013.

ZILBERBERG, Claude. Síntese da Gramática Tensiva. Revista Significação, São Paulo, v. 33, n. 25, p. 163-204, 2006.

Forma de citação sugerida:

FIORI, Fernando Martins. Argumentações e manipulações no filme Deus não está morto. EID\&A - Revista Eletrônica de Estudos Integrados em Discurso e Argumentação, Ilhéus, n. 15, p. 84-101, jan./jun.2018. 